\title{
The Problem of Confidence in Schoolteachers in The Context of New Normality
}

\author{
Lyudmila Alexeevna Brushkova ${ }^{1 *}$, Sergei Nazipovich Gavrov $^{2}$, Iosif Yurjevich Zaia ${ }^{3}$, Artur \\ Rudolfovuch Gevorkyan ${ }^{4}$, and Ekaterina Andreevna Manuilova ${ }^{5}$ \\ ${ }^{1}$ Financial University under the Government of the Russian Federation, Department of Sociology, \\ History and Philosophy, Moscow, Russia \\ ${ }^{2}$ Financial University under the Government of the Russian Federation, Department of Mass \\ Communications and Media Business, Moscow, Russia \\ ${ }^{3}$ Academy of Public Administration, Department of Social-Humanitarian Sciences, Services and \\ Cultural Heritage, Moscow, Russia \\ ${ }^{4}$ I.M. Sechenov First Moscow State Medical University, Department of Humanitarian Science, \\ Moscow, Russia \\ ${ }^{5}$ Center for quality assessment of education Profi.ru, Moscow, Russia
}

\begin{abstract}
The authors of the article have conducted a sociological study of the problem of confidence in schoolteachers in the Moscow region in autumn of 2019. They have interviewed teachers, students and their parents in the suburbs of Ramenskoye and the city of Orekhovo-Zuevo (these cities are located at different distances from Moscow), which has made it possible to see more clearly the socio-cultural specificity of the studied problem. In the article, the authors pay particular attention to the factors that affect mutual understanding between all the actors of the learning process. The authors conclude that the problem of confidence in schoolteachers is becoming more urgent, and the need for its systematic monitoring in schools appears. Considering the spread of distance learning, the authors of the article suggest that schoolteachers will face additional difficulties in building trusting relationships with students and their parents. The experience of the study, presented in the article, will be useful for finding solutions to the problem of confidence between all the actors of the learning process in changing conditions.
\end{abstract}

\section{Introduction}

Today, one of the most significant global trends in the scientific and educational sphere has become the search for the most optimal forms of transition to distance learning and the reasons for the prospects of the use of hybrid forms of the pedagogical process [1-13]. In this regard, the problem of confidence comes to the forefront in teachers' professional activity. The ability to achieve trusting relationships with students through direct personal communication in the classroom differs completely from the ability to achieve the same by working remotely or by combining distance learning and learning process in the classroom.

* Corresponding author: $\underline{\text { brushkova@yandex.ru }}$ 
Confidence in teachers includes several components. Not all of them can be affected by the teacher or school administration [14].

It is enough to mention such factor as schoolteachers' social status and its limited access to resources that are valuable in society. In the current situation, it is highly desirable to conduct ongoing sociological monitoring of confidence in teachers. It would give an idea of the local specificity of confidence in teachers, which was confirmed in a recent pilot study of this problem. In the Ramenskoye urban district, among schoolteachers, there are migrants from other Russian cities and from the countries of the former USSR (locals often prefer higher-paid jobs in Moscow, due to their proximity to the capital). Such teachers do not always have neither appropriate experience in teaching nor special education, which sometimes turns into their insecurity in classrooms, and, of course, they risk lacking confidence from students and their parents. In the city of Orekhovo-Zuevo, which is more distant from Moscow, a relatively stable teaching staff. Local teachers do not have the opportunity to work in Moscow, so they work in their district. They are respected in their city, since they have already worked with several generations of students, including those from local high social status families. The reason for declining confidence in teachers, who traditionally are considered carriers of knowledge and social values, is the instability of the value and sociocultural environment. Today people are hit by powerful streams of information, and it is easier to turn to "life hacks" not to a living person, but the Internet. Teachers, forced to resort to distance learning, sometimes feel like provincials and marginals, who act in a foreign environment generated by the development of information technology. At the same time, he is obliged not to get lost, to keep following his teaching mission, which limits the use of the techniques by which mass media representatives gain popularity [14].

The research aimed to study the confidence of the students and their parents in schoolteachers. The specificity of the research is in the fact that confidence in schoolteachers was compared with confidence in tutors and professors in the system of higher supplementary education.

\section{Methodology and materials}

The problem of confidence between all the actors of the learning process will continue to be actualized, but scientific approaches to it can quickly become obsolete. It can happen because confidence in the context of new normality is largely mediated by technologies that previously were not identified with the teaching profession. Educational activity involves three forms of confidence: interpersonal personified confidence (between teachers and students); interpersonal depersonalized confidence (in teachers as professionals, as a source of knowledge) and institutional confidence (in an educational institution), which were examined during our research.

The survey involved teachers, students and their parents from the Ramenskoye urban district and the city of Orekhovo-Zuevo (Moscow region). Special questionnaires were developed for each of these categories of respondents. They were also asked questions to identify the level of confidence in professors in the system of higher supplementary education and practising tutors. Summary tables were compiled according to the results.

Table 1. Students' confidence in teachers

\begin{tabular}{|l|l|l|l|l|}
\hline $\begin{array}{l}\text { Rate on a scale from 0 to } \\
10 \text { the level of confidence } \\
\text { in ... }\end{array}$ & $\begin{array}{l}\text { teacher as a } \\
\text { source of } \\
\text { knowledge }\end{array}$ & $\begin{array}{l}\text { teacher as a } \\
\text { person }\end{array}$ & $\begin{array}{l}\text { teacher as a } \\
\text { person to whom } \\
\text { you can entrust } \\
\text { personal } \\
\text { problems/rely } \\
\text { on }\end{array}$ & $\begin{array}{l}\text { total level of } \\
\text { confidence }\end{array}$ \\
\hline
\end{tabular}




\begin{tabular}{|l|l|l|l|l|}
\hline schoolteachers & 3 & 5 & 8 & 6 \\
\hline $\begin{array}{l}\text { professors in the system of } \\
\text { higher supplementary } \\
\text { education }\end{array}$ & 5 & 7 & 6 & 8 \\
\hline $\begin{array}{l}\text { tutors working privately or } \\
\text { in tutoring agencies }\end{array}$ & 8 & 8 & 9 & 5 \\
\hline
\end{tabular}

The most obvious gap in confidence in the teacher as a source of knowledge, as a person, and as a person to whom one can entrust personal problems, is observed referring to schoolteachers [2]. For the other two groups of educators, the lowest and highest confidence values do not diverge so much. Students have to see schoolteachers longer than others and in various situations, including when teachers are not able to adapt to each student and they even show their weaknesses. Teachers are subordinates in the relations with the school administration, so they are poorly protected from deviant students' insults. These students' negative attitude is sometimes formed by the scepticism of parents towards schoolteachers.

The confidence values for a university professor as a person is higher than other confidence values. There is an opinion that work in a university requires special personal qualities.

Tutors have the highest confidence values. They do not keep their distance from the student, unlike university professors, and are focused on the client. Students often consider tutors to be people with whom they can share problems in relations with teachers and communication with parents.

The value of confidence of a teacher as a source of knowledge looks low for schoolteachers, especially if to compare it with tutors. Only tutors have the opportunity to approach every student individually.

Schoolteachers receive the lowest value of confidence as a source of knowledge. Schoolteachers are not always competent, they are not freely chosen and easily changed, as tutors. They combine several areas of study, which are not always compatible, at the same time (preparation for the Unified State Exam, teaching, etc.). They are distracted by bureaucratic procedures, are not able to satisfy the needs in information of each student due to the different level of education of students.

Students sometimes extrapolate some personal complaints on perceived individually teachers, including those to teachers' objectivity. Attempts to stimulate independent work, the volume of which is growing immeasurably with the spread of distance learning, are perceived by some parents as evidence of teacher incompetence. Thus, the problem of confidence turns out to be closely related to the problem of mutual understanding and the sociocultural characteristics of families of students.

Table 2. Students' interpersonal confidence

\begin{tabular}{|l|l|}
\hline Who are you likely to contact in a difficult situation? \\
\hline one of the parents & mother, grandmother $89 \%$ \\
\hline teacher & $53 \%$ \\
\hline peer friend & $40 \%$ \\
\hline other & $20 \%$ \\
\hline
\end{tabular}

The data, presented in the table, indicate the preservation of a certain patriarchal character in the Russian families [15].

Table 3. Social expectations of parents from their children's learning process at school

\begin{tabular}{|l|l|}
\hline What result do you expect from your child's learning process at school? \\
\hline preparation for the Unified State Exam & $30 \%$ \\
\hline giving knowledge demanded in later life & $38 \%$ \\
\hline
\end{tabular}




\begin{tabular}{|l|l|}
\hline developing social and cultural skills & $50 \%$ \\
\hline developing information competences & $47 \%$ \\
\hline developing communicative competences & $60 \%$ \\
\hline vocational guidance, choosing and building career paths & $54 \%$ \\
\hline school is useless to all above-mentioned purposes & $3 \%$ \\
\hline
\end{tabular}

School is perceived by parents as an institution that provides general training. Preparation for the Unified State Exam is considered to be a quite specialized activity (to a certain extent, exams can also be chosen). Yet, the school fails to carry it out properly. However, tutors rely on the information, which is systematically given by schoolteachers to students. Their work appears to be "hidden" and therefore underestimated.

Table 4. Teacher's opinion about the main problems encountered in professional activity

\begin{tabular}{|l|l|}
\hline What is interfering with your professional activity? \\
\hline lack of teacher's authority in society & $85 \%$ \\
\hline $\begin{array}{l}\text { poor conditions (low wages, irregular working hours, overtime work without } \\
\text { further payment) }\end{array}$ & $82 \%$ \\
\hline technical insecurity of the learning process (inadequate physical infrastructure) & $75 \%$ \\
\hline lack of prestige of teaching professions & $84 \%$ \\
\hline administration and colleagues' attitude towards teachers & $67 \%$ \\
\hline children's attitude towards teachers & $50 \%$ \\
\hline parents' attitude towards teachers & $64 \%$ \\
\hline
\end{tabular}

\section{Conclusion}

The conducted research allows concluding that there exists a connection between the level of confidence in teachers and their social status. Most of the schoolteachers face the problem when students and parents lack confidence in them. One of the reasons for it is the declining prestige of teaching professions in our society.

Our study was conducted even before the well-known events that prompted educational institutions to switch totally to distance learning. Yet, despite this, the study highlights the main weaknesses that should be paid attention to when studying the problem of confidence in teachers in drastically changing conditions.

With the spread of distance learning and the further weakening of the schools' socialization function, which is intercepted by the media, tutors and teachers can become competitors.

The tendency to identify the schooling results with the results of passing the Unified State Exam will be reinforced. The value of school education should not be reduced to the successful passing of exams, but one can affirm this only as long as the learning process in classroom prevails over distance learning.

The territorial monopoly, which the majority of Russian general education schools has always had, is unlikely to remain the same after the transferring of educational activities into virtual space. It is the reason for the inevitable greater competition between schools and between teachers themselves. Both of them will have to resort to market methods of attracting "customers", and therefore to targeted strategies for building up confidence with all the further consequences.

In this regard, our study, which compares the levels of confidence in schoolteachers, professors in the system of higher supplementary education and practising tutors, can be useful for organizing a successful schoolteachers' professional activity.

\section{References}


1. E. Petrash, T. Sidorova, Experience in the Implementation of the Parental Enlightenment Program "Axioms of Parental Love", Society. Integration. Education. Proceedings of the International Scientific Conference May 21, Pskov, Russia (2019)

2. A.S. Delliana, A.M. Wibowo Wook, Bigo Live: Ethical Degradation in Communication (A Critical Study of Communication in a Computer- Mediated Communication Perspective), in Proceedings of the Tarumanagara International Conference on the Applications of Social Sciences and Humanities (TICASH 2019), Advances in Social Science, Education and Humanities Research 439, 83-88 (2019)

3. J. Matochová, Experience with the Middle School Inclusion in the Czech Republic, Advances in Social Science, Education and Humanities Research, in 2nd International Conference on Education Science and Social Development (2019)

4. Y. Sui, A Brief Analysis on the Necessity of the College Ideological and Political Education under the Background of New Media, in Proceedings of the 2nd International Conference on Education Science and Social Development (ESSD 2019), Advances in Social Science, Education and Humanities Research 298, 378-381 (2019)

5. M. Osipov, N. A. Matveyeva, P. A. Boyadzhiyeva, Ya. A. Vorontsov, Sotsiologicheskiye issledovaniya 46(3), 60-70 (2020)

6. J.E. Vittek, SAGE Open 5(2), 1-6 (2015).

7. Q. Cui1, SAGE Open 6(3), 1-9 (2016)

8. K. Frimpong, SAGE Open 5(2), 1-14 (2015)

9. K. Rao, G. Meo, SAGE Open 4(6), 1-12 (2016)

10. D. Ginting, A. Saukah, SAGE Open 6(4), 1-7 (2016)

11. J.L. Berger, C. Girardet, C. Vaudroz, M. Crahay, SAGE Open 8(1), 1-12 (2018)

12. K.A. Hicks, SAGE Open 8(2), 1-9 (2018)

13. A. Lepp, J.E. Barkley, A.C. Karpinski, S. Singh, SAGE Open 9(1), 1-9 (2019)

14. A. M. Osipov, N. A. Matveyeva, P. A. Boyadzhiyeva, Ya. A. Vorontsov, Sotsiologicheskiye issledovaniya 46(3), 60-70 (2020)

15. Ye.A. Manuylova, Otechestvennyy zhurnal sotsialnoy raboty 5, 79-86 (2015)

16. S. Gavrov, Russian journal of communication, London 9(2), 207-210 (2017) 